Original Article

\title{
Molecular characterization of Aeromonas hydrophila isolates from diseased fishes in district Kasur, Punjab, Pakistan
}

\author{
Caracterização molecular de isolados de Aeromonas hydrophila de peixes doentes no \\ distrito de Kasur, Punjab, Paquistão
}

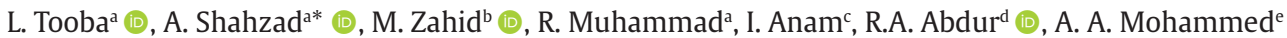 \\ and H. M. Mater ${ }^{\mathrm{f}}$
}

aUniversity of Veterinary and Animal Sciences, Department of Wildlife \& Ecology, Discipline of Zoology, Wildlife Epidemiology and Molecular Microbiology Laboratory (One Health Research Group), Lahore, Ravi Campus, Pattoki, Pakistan

bUniversity of Azad Jammu and Kashmir, Department of Biotechnology, Chehla Campus, Muzaffarabad, Azad Kashmir, Pakistan 'University of Veterinary and Animal Sciences, Department of Biological Sciences, Lahore, Ravi Campus, Pattoki, Pakistan dThe University of Lahore, Department of Zoology, Sargodha Campus, Sargodha, Pakistan

eNajran University, Faculty of Applied Medical Sciences, Department of Clinical Laboratory Sciences, Najran, Saudi Arabia

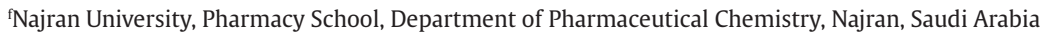

\begin{abstract}
Pakistan is an agricultural country and fisheries play a very important role in the economic development of the country. Different diseases are prevalent in Pakistani fish but information related to the causative agents is not wellknown. Keeping in view the significance of bacterial pathogens as the causative agents of multiple fish diseases, the present study was conducted for identification, characterization and analysis of virulence genes of Aeromonas spp. isolated from diseased fishes. A total of fifty fish samples having multiple clinical indications were collected from different fish farms of district Kasur, Punjab Pakistan. For isolation of Aeromonas spp. samples were enriched and inoculated on Aeromonas isolation medium. Isolates were identified and characterized by different biochemical tests, Analytical Profile Index (API) 20E kit and Polymerase Chain Reaction (PCR) assays. All isolates were screened for three putative virulence genes including aerolysin (aer), haemolysin (hyl) and heat labile cytotonic enterotoxin (alt). Seven isolates of Aeromonas (A.) hydrophila were retrieved and identified based on API 20E. These isolates were further confirmed as A. hydrophila on the basis of PCR assays. Three isolates were detected positive for the presence of virulence genes (alt and hyl). Whereas aerolysin (aer) gene was not present in any of A. hydrophila isolates. The present study confirmed $A$. hydrophila as the causative agent of epizootic ulcerative syndrome and motile Aeromonas septicemia in fish farms of district Kasur, Punjab Pakistan. Moreover, detection of two virulence genes (alt and hyl) in A. hydrophila isolates is a threat for fish consumers of study area.
\end{abstract}

Keywords: Aeromonas hydrophila, EUS, MAS, virulence genes, fish.

\section{Resumo}

O Paquistão é um país agrícola, onde a pesca desempenha um papel muito importante para o desenvolvimento econômico. Diferentes doenças são prevalentes em peixes do Paquistão, mas as informações relacionadas aos agentes causadores não são bem conhecidas. Tendo em vista a importância dos patógenos bacterianos como agentes causadores de múltiplas doenças em peixes, o presente estudo foi conduzido para identificação, caracterização e análise de genes de virulência de isolados de Aeromonas spp. de peixes doentes. Foram coletadas 50 amostras de peixes com múltiplas indicações clínicas em diferentes fazendas do distrito de Kasur, Punjab, Paquistão. Para isolar Aeromonas spp., as amostras foram enriquecidas e inoculadas em meio de isolamento. Os isolados foram identificados e caracterizados por diferentes testes bioquímicos, kit Analytical Profile Index (API) 20E, e ensaios de reação em cadeia da polimerase (PCR). Todos os isolados foram selecionados para três genes de virulência putativos, incluindo aerolisina (aer), hemolisina (hyl) e enterotoxina citotônica termolábil (alt). Sete isolados de Aeromonas hydrophila foram recuperados e identificados com base no API 20E. Esses isolados foram posteriormente confirmados como A. hydrophila de acordo com ensaios de PCR. Três isolados indicaram a presença de genes de virulência (alt e hyl), enquanto o gene aerolisina (aer) não esteve presente em nenhum dos isolados de A. hydrophila. O presente estudo confirmou A. hydrophila como o agente causador da síndrome ulcerativa epizoótica e septicemia móvel por Aeromonas em fazendas de peixes, no distrito de Kasur, Punjab, Paquistão. Além disso, a detecção de dois genes de virulência (alt e hyl) em isolados de A. hydrophila é uma ameaça para os consumidores de peixes da área de estudo.

Palavras-chave: Aeromonas hydrophila, EUS (Síndrome Ulcerativa Epizoótica), MAS (septicemia móvel por Aeromonas), genes de virulência, peixes.

*e-mail: shahzad.ali@uvas.edu.pk

Received: July 30, 2021 - Accepted: September 23, 2021

This is an Open Access article distributed under the terms of the Creative Commons Attribution License, which permits unrestricted use, distribution, and reproduction in any medium, provided the original work is properly cited. 


\section{Introduction}

As a result of population explosion, satisfying safe, sufficient and nutritious diet have become a global issue. To reduce pressure on food crops, a trend has been observed in utilization other foods such as Fish. Fish is not only a delicious and nutritious part of human diet but of animal feed as well. To meet the growing demand of fish and its products, the freshwater fish culture sector is developing using various modern techniques (Govind et al., 2012; Mert and Bulut, 2014). However, the fisheries sector is confronting numerous difficulties despite its fast development. Among these, substantial financial losses in terms of infections play an essential part. Freshwater fishes are spoiled with various infections of bacterial, viral, fungal and parasitic origins. One of the most critical fish illnesses are bacterial infections, responsible for huge loss in the form of fish mortality (Dias et al., 2012) such as dropsy, tuberculosis, gill spoil, tail decay, fin rot, scale oedema and furunculosis.

Motile Aeromonas septicaemia (MAS) and epizootic ulcerative syndrome (EUS) are two of the bacterial diseases of fish associated with considerable financial losses (Jagoda et al., 2014). Many members of Aeromonas genus are responsible for MAS (Viji et al., 2012) and EUS. However, EUS is most noticeably caused by A. hydrophila, A. sorbia, A. veroni and A. Caviae (Oidtmann et al., 2008). While A. hydrophila is the most opportunistic, well-known pioneering pathogens of fish, which has been examined as the causative factor for motile Aeromonas septicaemia and ulcer disorder (Shao et al., 2004).

Aeromonas hydrophila is a gram-negative, motile and curved edged heterotrophic bacterium (bacilli to coccobacilli shape), which does not form endospores. Generally these are present in temperate climate zones and inhabit natural, estuarine, chlorinated, salt, marine, and un-chlorinated waters (Markov et al., 2007).

Aeromonas hydrophila integrates a range of strains or genotypes having pathogenic potential at one extreme and avirulence at the other conferring little damage to the host. Analysis of pathogenic system related with A. hydrophila has revealed harmful factors consolidating poisons which are actually heat labile cytotonic enterotoxin (Alt), cytotoxic enterotoxin (Act), serine Protease (ahp) and Aerolysin (Aer). However little attention has been devoted towards the relative frequency of virulence genes in Aeromonas isolated from unhealthy fish and water bodies (Cascon et al., 2000; Singh et al., 2009). Aeromonas species have a tendency to transfer these genes to other microorganisms and environment and vice versa. The detection of these virulence genes in microbes inhabiting diverse hosts can help in risk assessment of cross species transmission and environmental monitoring for contaminating these genes (Roges et al., 2020). The virulent genes associated with pathogenic strains of $A$. hydrophila isolated from fish has been detected in Vietnam (aerA, act), Egypt (aerA, altA) and Tanzania (aer, hly, fla) (Kishk et al., 2020; Mzula et al., 2020; Nhinh et al., 2021).

Around the world, information regarding characterizations, PCR based identification and detection virulence gene of bacterial pathogens have been thoroughly explored, such as in USA, Egypt, India and Spain (GonzalezSerrano et al., 2002; Pridgeon and Klesius, 2011 and Sarkar et al., 2013). Unfortunately, Pakistan is standing as an exception to above mentioned countries, with just three reports describing the occurrence of epizootic ulcerative syndrome and haemorrhagic septicaemia in fresh water or dam water (Rab et al., 2001; Shahzad et al., 2014; Ali et al., 2016). Another concern in developing prevention and control strategies of fish diseases in Pakistan is insufficient data relevant to the causative agents of fish diseases. Only two studies provide information about $A$. hydrophila and A. sorbia as the causative agents of epizootic ulcerative syndrome and haemorrhagic septicaemia in farmed and wild fish of Pakistan (Shahzad et al., 2014; Ali et al., 2016). Keeping in view the significance of Aeromonas species as the causative agent of multiple fish diseases, this study aimed to characterize Aeromonas isolates and detection of virulence genes in Aeromonas species from disease fish in district Kasur Pakistan.

\section{Materials and Methods}

\subsection{Study area}

The present study was conducted in different fish farms of district Kasur, Punjab Pakistan. District Kasur lies from 75‥585"E to 73.623"E and 31.363"N to 30.663"N. District Kasur is administratively subdivided into four tehsils i.e. Chunian, Kasur, Kot Radha Kishan and Pattoki (Figure 1). Both government and private sector fish farms are present in these tehsils. Commonly cultured fishes in these farms are rohu (Labeo rohita), grass carp (Ctenopharyngodon idella), gulfam (Cyprinuscarpio), mori (Cirrhinus mrigala), silver carp (Hypophthalmichthys molitrix) and tilapia (Oreochromis niloticus). Two types of ponds (mud and cemented) have been observed in district Kasur region but mostly farms have mud ponds. The common water source is tube-well. Organic and inorganic manures are used for fertilization of fish ponds. There are evidences of problems associated with fish health and growth retardation in this area.

\subsection{Sample collection and transportation}

A total of fifty fish samples having disease symptoms were collected (December 2017 to March 2018) from fish farms of district Kasur, Punjab Pakistan. Ten samples from each fish species were collected including rahu (Labeo rohita), grass carp (Ctenopharyngodon idella), gulfam (Cyprinus carpio), mori (Cirrhinus mrigala) and tilapia (Oreochromis niloticus), all of which were infected with motile Aeromonas septicemia and epizootic ulcerative syndrome. These samples were then kept into ice box after putting inside zip-lock bags and were transported to laboratory for further processing.

\subsection{Isolation and primary characterization of Aeromonas isolates}

Epidermal muscle, kidney and liver tissues were collected by sterilized forceps from dissected fish, transferred to tryptic soya broth (Himedia Laboratories Pvt. 


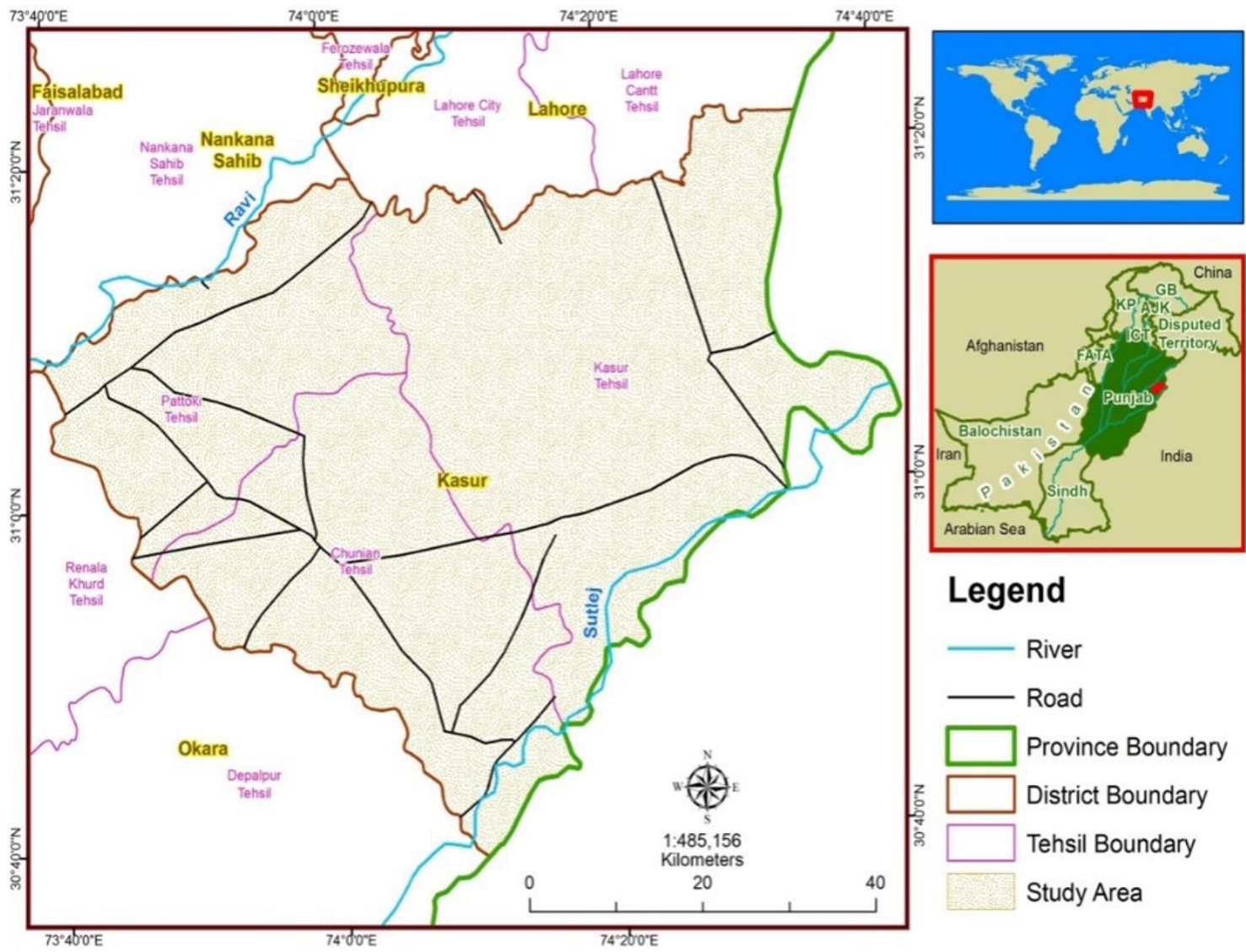

Figure 1. Study area map of district Kasur including tehsil Pattoki, Chunian, Kasur, and Kot Radha Kishan.

Ltd, Mumbai India) and incubated at $37^{\circ} \mathrm{C}$ for 24 hours for enrichment (Shahzad et al., 2014). After enrichment samples were inoculated on Aeromonas isolation medium (Himedia Laboratories Pvt. Ltd, Mumbai India) and incubated at $28^{\circ} \mathrm{C}$ to $37^{\circ} \mathrm{C}$ for 24 hours. Suspected Aeromonas colonies were selected on the basis of green colour and smooth shape, after that gram staining was done according to a reported procedure (Zhou et al., 2013). Morphologically observed colonies were re-inoculated on tryptic soya agar (Himedia Laboratories Pvt. Ltd, Mumbai India) for pure culture and then these isolates were preserved in 50\% glycerol till further analysis.

\subsection{Biochemical characterization}

Initial biochemical identification of isolates was performed using oxidation, coagulation, catalase, vogesproskauer and indole production tests by standard method described by Bergey's manual of systematic bacteriological classification. Moreover, all pure isolates were confirmed by API 20E (Biomerieux, France). Briefly, sample suspension was prepared by dissolving fresh colonies in normal saline and turbidity was adjusted by using $0.5 \mathrm{McFarland}$ standard. All the sections of strip were carefully inoculated according to the manufacturer instructions. To create anaerobic conditions after inoculation, some specific sections were covered with sterile mineral oil. The arranged strip was enclosed with a lid and incubated for $1-2$ days at $24^{\circ} \mathrm{C}$. After incubation, all reactions were logged (Nahar et al., 2016).

\subsection{Extraction of DNA}

DNA was extracted from pure culture using FavorPerp ${ }^{\mathrm{TM}}$ DNA extraction mini kit according to manufacturer instructions (Favorgen Biotech Crop, Taiwan). DNA was preserved at $-20^{\circ} \mathrm{C}$ for additional studies.

\subsection{PCR based confirmation}

Aeromonas genus (953 bp) and species specific (for $A$. hydrophila $=103 \mathrm{bp)} 16 \mathrm{~S}$ rRNA PCR assays were done as described in previous published literature (Lee et al., 2002; Trakhna et al., 2009). A $25 \mu l$ reaction mixture contains $12 \mu \mathrm{l}$ of $2 x A m p$ Taq master mix (GeneAll cat\# 541-005), $1 \mu \mathrm{l}$ forward and reverse primer (Humanizing Genomics Microgen), $2.5 \mu$ DNA template and $8.5 \mu$ distilled water was used for PCR amplifications.

\subsection{Detection of virulence genes}

All isolates of $A$. hydrophila were screened against three virulent genes as previously described by Zhou et al. (2013) Table 1. Amplification was performed by initial denaturation at $94{ }^{\circ} \mathrm{C}$ for 5 minutes ( $\mathrm{min}$ ), followed by 30 cycles with denaturation at $94{ }^{\circ} \mathrm{C}$ for 30 seconds (s), 
annealing at $60^{\circ} \mathrm{C}$ for $30 \mathrm{~s}$ for the alt and hyl gene or for aer gene initial denaturation at $94^{\circ} \mathrm{C}$ for $5 \mathrm{~min}$, denaturation at $94{ }^{\circ} \mathrm{C}$ for $30 \mathrm{~s}$, annealing at $55^{\circ} \mathrm{C}$ for 30 s and extension at $72{ }^{\circ} \mathrm{C}$ for $1 \mathrm{~min}$. A final extension step was carried out at $72{ }^{\circ} \mathrm{C}$ for $10 \mathrm{~min}$.

\subsection{Agarose gel electrophoresis}

Visualization of positive amplicons was confirmed in $1.5 \%$ Agarose gel by electrophoresis (bioWORLD, bioPLUS Fine Research Chemicals Cat\# 40100164-4) after being stained with ethidium bromide. The amplified DNA fragments of specific size were visualized by UV fluorescence and recorded by using a gel imager (BioRad Gel Doc EZ imager).

\section{Results}

\subsection{Bacteriological observation and morphological characteristics of isolates}

In the present study a total of seven A. hydrophila isolates were recovered from five different diseased fishes
Table 2. Among all seven isolates three (42.8\%) were obtained from the kidney and liver of rohu (Labeo rohita) and tilapia (Oreochromis niloticus) and four (57.1\%) were isolated from epidermal muscle of same (rohu (Labeo rohita), tilapia (Oreochromis niloticus) along with grass carp (Ctenopharyngodon idella) as well.

On the basis of conventional biochemical tests and API 20E, all isolates were characterized as A. hydrophila. Morphologically isolated colonies were opaque having a darker centre as compared to periphery of Aeromonas isolation medium and yellowish opaque, smooth edged, convex, round, and semi-translucent colonies on TSA plates Table 3.

\subsection{Biochemical characterization by conventional method}

The biochemical characteristics of the isolates performed by conventional methods are summarized in Table 4 . All isolates were rod shaped, gram negative and were positive towards oxidase, coagulase, voges-proskauer, catalase and indole. Subsequently, isolates showed positive growth at $37{ }^{\circ} \mathrm{C}$ with the optimum time of 24 hours but no growth was observed at $28^{\circ} \mathrm{C}$ and $30^{\circ} \mathrm{C}$.

Table 1. Primers used to detect the virulence genes in Aeromonas hydrophila.

\begin{tabular}{cccc}
\hline Target genes & Primer Sequences (5'-3') & bp & References \\
\hline Aerolysin (aer) & GCTGAACCATCTATCCTG & 301 & Zhou et al. (2013) \\
TTTCTCCGGTAACAGGATTG & & \\
Haemolysin (hyl) & GGCCGGTGGCCCGAAGATACGGG & 600 & \\
GGCGGCGCCGGACGAGACGGG & & 442 \\
(alt) & TGACCCAGTCCTGGCACGGC & & \\
\hline
\end{tabular}

Table 2. Detail of culture positive disease fish species and targeted organs.

\begin{tabular}{|c|c|c|c|c|}
\hline $\begin{array}{c}\text { Sample } \\
\text { No. }\end{array}$ & Sample Type & Fish Species & Disease & $\begin{array}{c}\text { Aeromonas } \\
\text { Species }\end{array}$ \\
\hline $1(\mathrm{a})$ & Kidney & Labeo rohita & EUS & A. hydrophila \\
\hline 1 (b) & Liver & Labeo rohita & EUS & A. hydrophila \\
\hline $2(a)$ & Liver & Oreochromis niloticus & MAS & A. hydrophila \\
\hline 2 (b) & Epidermal muscle & Oreochromis niloticus & MAS & A. hydrophila \\
\hline 3 & Epidermal muscle & Ctenopharyngodon idella & MAS & A. hydrophila \\
\hline 4 & Epidermal muscle & Labeo rohita & MAS & A. hydrophila \\
\hline 5 & Epidermal muscle & Labeo rohita & EUS & A. hydrophila \\
\hline
\end{tabular}

Table 3. Physiological characterization of Aeromonas isolated from diseased fish.

\begin{tabular}{lll}
\hline \multicolumn{1}{c}{ Test } & \multicolumn{1}{c}{ Result } & Number (\%) \\
\hline $\begin{array}{l}\text { Colony Color on Aeromonas Isolation } \\
\text { Medium }\end{array}$ & Dark Green, Opaque with Dark Centre & $7(100)$ \\
Colony Color on TSA & Tan/buff-color & $7(100)$ \\
Colony Shape & Smooth, Convex and Rounded & $7(100)$ \\
\hline
\end{tabular}




\subsection{Identification by API 20E Kit}

Twenty tests were performed by using API 20E kit according to manufacturer's instructions. All positive and negative results are summarized in Table 5 . All isolates $(n=7)$ showed positive results towards ADH, AMY, LDC, IND, AP, GEL, GLU, ONPG, TDA, MAN, SAC, MEL, CIT and
ARA. However, negative reactions were shown for ODC, INO, RHA, SOR, H2S and URE.

\subsection{PCR based confirmation and virulence gene detection}

All seven isolates were positive for Aeromonas genus (953 bp) and species (A. hydrophila $=103$ bp) (Figure 2).

Table 4. Biochemical characteristics of $A$. hydrophila isolates determined by conventional methods.

\begin{tabular}{|c|c|c|c|c|c|c|c|c|}
\hline \multirow{2}{*}{ Characteristics } & \multicolumn{8}{|c|}{ Response of Aeromonas isolates } \\
\hline & & A1 & A2 & A3 & A4 & A5 & A6 & A7 \\
\hline Gram Stain & & - & - & - & - & - & - & - \\
\hline Motility & & + & + & + & + & + & + & + \\
\hline Shape & & & & & Rod & & & \\
\hline Coagulase & & + & + & + & + & + & + & + \\
\hline Catalase & & + & + & + & + & + & + & + \\
\hline Oxidase & & + & + & + & + & + & + & + \\
\hline Voges Proskauer & & + & + & + & + & + & + & + \\
\hline Indole & & + & + & + & + & + & + & + \\
\hline \multirow{3}{*}{$\begin{array}{l}\text { Growth at different } \\
\text { temperature }\end{array}$} & $28^{\circ} \mathrm{C}$ & - & - & - & - & - & - & - \\
\hline & $30^{\circ} \mathrm{C}$ & - & - & - & - & - & - & - \\
\hline & $37^{\circ} \mathrm{C}$ & + & + & + & + & + & + & + \\
\hline
\end{tabular}

F: Fermentative; (+): Positive response; (-): Negative response.

Table 5. Analytical profile index (API 20E) of isolates.

\begin{tabular}{|c|c|c|}
\hline Test & Characteristics & Results (\%) \\
\hline \multirow[t]{20}{*}{ API 20E } & Beta-galactosidase (ONPG) & $+(100)$ \\
\hline & Arginine dihydrolase (ADH) & $+(100)$ \\
\hline & Lysine Decarboxylase (LDC) & $+(100)$ \\
\hline & Ornithine Decarboxylase (ODC) & $-(100)$ \\
\hline & Citrate utilisation (CIT) & $+(100)$ \\
\hline & $\mathrm{H} 2 \mathrm{~S}$ production $(\mathrm{H} 2 \mathrm{~S})$ & $-(100)$ \\
\hline & Urease production (URE) & $-(100)$ \\
\hline & Tryptophane deaminase (TDA) & $+(100)$ \\
\hline & Indole production (IND) & $+(100)$ \\
\hline & Acetoin production (AP) & $+(100)$ \\
\hline & Gelatinase (GEL) & $+(100)$ \\
\hline & Glucose (GLU) & $+(100)$ \\
\hline & Mannitol (MAN) & $+(100)$ \\
\hline & Inositol (INO) & $-(100)$ \\
\hline & Sorbitol (SOR) & $-(100)$ \\
\hline & Rhamnose (RHA) & $-(100)$ \\
\hline & Sucrose (SAC) & $+(100)$ \\
\hline & Melibiose (MEL) & $+(100)$ \\
\hline & Amygdalin (AMY) & $+(100)$ \\
\hline & Arabinose (ARA) & $+(100)$ \\
\hline
\end{tabular}

(+): Positive response; (-): Negative response 
Table 6. Virulence genes detection of Aeromonas hydrophila isolated from diseased fish.

\begin{tabular}{cccccc}
\hline Sample no & $\begin{array}{c}\text { Aeromonas } \\
\text { genus }\end{array}$ & $\begin{array}{c}\text { Aeromonas } \\
\text { hydrophila }\end{array}$ & $\begin{array}{c}\text { Haemolysin } \\
(\text { hyl) }\end{array}$ & Aerolysin (aer) & $\begin{array}{c}\text { Cytotonic } \\
\text { enterotoxin (alt) }\end{array}$ \\
\hline A1 & + & + & - & - & - \\
A2 & + & + & - & - & - \\
A3 & + & + & + & - & - \\
A4 & + & + & + & - & + \\
A5 & + & + & - & - & - \\
A6 & + & + & - & - & + \\
A7 & + & + & & - \\
\hline
\end{tabular}

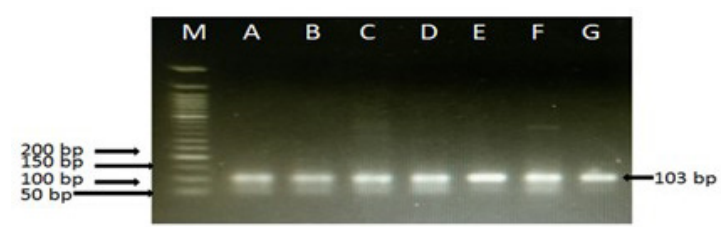

Figure 2. PCR based identification of Aeromonas hydrophila, Lane M: (left to right) 50 bp ladder marker (GeneOn), Lane A-G field isolates of Aeromonas hydrophila 16S rDNA (103 bp) primer amplification.

The distribution of virulence genes among all A. hydrophila isolates is summarized in Table 6. Virulence gene detection revealed that three out of seven $(42.8 \%)$ isolates were positive for hyl and alt genes Figure 3 and 4. There was no positive isolate for aer gene.

\section{Discussion}

Despite the fact that the aquaculture sector is facing many challenges with respect to bacterial diseases all around the world and these diseases have a negative impact on the economic affluence of aquaculture fields; still very less determination is observed towards focusing on this aspect of the field (Elsheshtawy et al., 2019).

In present study, different fish species were found infected with MAS and EUS. Which indicates that these species are equally susceptible for these bacterial diseases. Similar findings have been reported from Pakistan in previous studies (Rab et al., 2001; Ali et al., 2016). Our findings are in line with Algammal et al. (2020), who found high prevalence of MAS in different farmed fishes of Egypt. Similarly, from Malaysia, India, China, Serbia and Tanzania and Portugal, same results have been documented (Li et al., 2011; Dias et al., 2012; Sarkar et al., 2013; Laith and Najiah, 2014). This particular similarity is a clue of cosmopolitan distribution of these bacterial diseases.

In present study, A. hydrophila were obtained from kidney, liver and epidermal muscle of tilapia (Oreochromis niloticus), rohu (Labeo rohita) and grass carp (Ctenopharyngodon idella) during the study, which is also evident from results of previous study in which Aeromonas spp. was highlighted as one of the most common diseasecausing agents in the aquatic ecosystem (Hassan et al.,

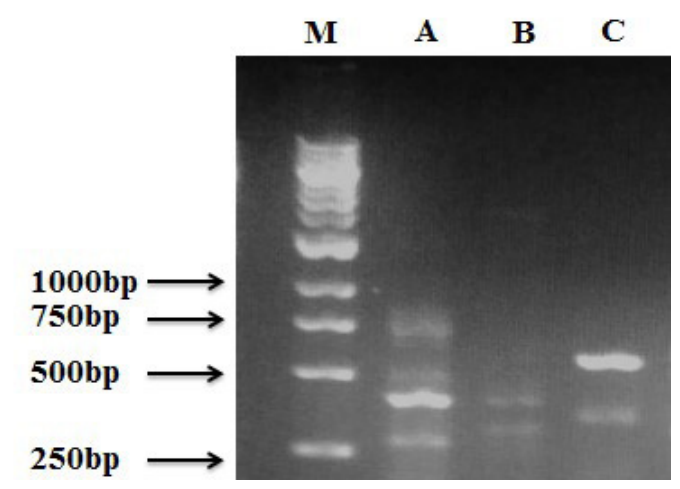

Figure 3. PCR based detection of haemolysin (hyl) gene, Lane M: (left to right) $1 \mathrm{~kb}$ ladder (GeneOn) Lane $\mathrm{C}$ has amplicon (600 bp) of haemolysin (hyl) gene.

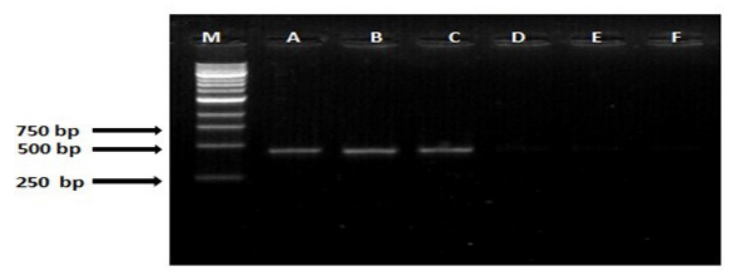

Figure 4. PCR based detection of heat labile cytotonic enterotoxin (alt) gene, Lane M: (left to right) $1 \mathrm{~kb}$ ladder (GeneOn), Lane A, B and $C$ has amplicons (442 bp) of heat labile cytotonic enterotoxin (alt) gene.

2017). In a comparable study A. hydrophila was isolated from different diseased wild and farmed fishes in Potohar region Pakistan (Ali et al., 2016).

In another study conducted in Egypt A. Veronii was detected from Oreochromis niloticus that is an important pathogen for bacterial fish diseases which has been isolated from different organs i.e. liver, spleens, kidney and brain (El Latif et al., 2019). Similar results were also reported from tilapia in Thailand and Vietnam (Peepim et al., 2016; Dong et al., 2017). On the other hand, 33/250 (13.2\%) tilapia (Oreochromis niloticus) was contaminated with $A$. hydrophila from El-Sharkia Governorate, Egypt. The highest prevalence was recorded in the liver (54.10\%) other than all 
infected organs (Algammal et al., 2020). Moreover, eleven strains of $A$. hydrophila and three strains of $A$. veronii were isolated from freshwater fish species from a study too place in Ponferrade Leon, Spain (Gonzalez-Serrano et al., 2002).

The colonies of $A$. hydrophila were green, opaque with dark center on Aeromonas isolation medium while on TSA medium the isolated colonies color Tan/buff with smooth surface. All isolates were gram negative, rod shaped and pink in color. These results are correlated with the previous studies such as of Dong et al. (2017) and El Latif et al. (2019), who isolated Aeromonas species from tilapia with the same morphological and biochemical characteristics as aeromonads. Current study numeric outcomes are also in agreement with previous study of Mansour et al. (2019), in which they isolated A. hydrophila from diseased tilapia (Oreochromis niloticus) in Egypt and reported the same morphological and biochemical characteristics (Wanja et al., 2019).

API-20E kit was used for confirmation of A. hydrophila, which ultimately showed that isolated bacteria had biochemical characters resembling with $A$. hydrophila. Similarly, studies carried out in other parts of world such as in Mymensingh, Bangladesh (Nahar et al., 2016) for identification of isolates of $A$. hydrophila from Juvenile farmed Pangasius (Pangasianodon hypophthalmus) by using same kit claimed ten isolated bacteria to be positive towards ADH, AMY, LDC, IND, AP, GEL, GLU, ONPG, TDA, MAN, SAC, MEL, CIT and ARA. Negative reactions were shown for ODC, INO, RHA, SOR, $\mathrm{H}_{2} \mathrm{~S}$ and URE. I. Our results are also coherent with the findings of Dong et al. (2017), who isolated Aeromonas from Nile tilapia from Pathum Thani Province, Thailand.

Biochemically identified isolates were further confirmed by genus (Aeromonas) and species (A. hydrophila) level using 16S rRNA approach by PCR assays. All recovered isolates were positive for genus Aeromonas (953 bp). Our results are in accordance with that documented in article by Aboyadak et al. (2015) who observed Aeromonas having 953 bp isolated from tilapia in Egypt. Same results were detected by Matter et al. (2018) at Kafr El-Sheikh, Egypt who detect the Aeromonas from freshwater fish species (O. niloticus. C. Gariepinus and M. cephalusat). All genus amplified isolates were positive for $A$. hydrophila having amplicon size of $103 \mathrm{bp}$. Our results are similar with those obtained by Aboyadak et al. (2015) who confirmed 12 isolates of $A$. hydrophila at the same band size (103 bp) of DNA fragments isolated from Tilapia at Kafr El-Sheikh north of Egypt. A similar finding was observed in another study that isolated A. hydrophila (103 bp) from fish water samples in France, Tunisia and Lebanon the (Trakhna et al., 2009).

In our study, it is evident that the prevalence of the alt and hyl gene is the most common virulence gene of $A$. hydrophila. Similar studies have been conducted in other countries such as Canada, China, India, Malaysia and Spain (Wang et al., 2003; Pridgeon and Klesius, 2011; Zhou et al., 2013). In addition, three strains of $A$. hydrophila had alt and hyl having amplicon size 600 and $442 \mathrm{bp}$. These figures can be correlated with that of Algammal et al. (2020), who reported alt genes isolation from infected tilapia (Oreochromis niloticus). Some recent published data such as in case of Hossain et al. (2020), reported $80.8 \%$ hyl and $48.1 \%$ alt gene, which is a fair source of evidence to support our results. On the other side Mansour et al. (2019) found 5/21 hyl genes from diseased fish of Kafr El-Shaikh Egypt. However, a previous study conducted in Spain showed that eleven strains of $A$. hydrophila isolated from freshwater fish were positive for hyl gene (Gonzalez-Serrano et al., 2002).

In contrast, our result revealed that none of $A$. hydrophila strains had harboured aer gene. These results were in disagreement with Eid et al. (2019), who concluded that aer was the most dominant gene in diseases fish with $100 \%$ prevalence. $73.1 \%$ of $A$. hydrophila isolates from diseased ornamental guppy (Poecilia reticulata) were reported with aer gene from Seoul, Korea Hossain et al. (2020).

In conclusion our study indicated that $A$. hydrophila and its virulence genes have a considerable role in imparting diseases to fish. Screening of specific heat labile cytotonic enterotoxin (alt) and haemolysin (hyl) genes seems to be the most effective way for detecting virulence properties of $A$. hydrophila. It is necessary that fish farms should be monitored regularly to identify Aeromonas at broad spectrum for identification of pathogens and management of disease outbreaks in aquaculture. API 20E kit and polymerase chain reaction are the best possible conventional approaches for a further detection and assessment of Aeromonas species in the food, environment and to prevent human health risk.

\section{Acknowledgements}

This study was supported by the Higher Education Commission (HEC), Pakistan funded project. We also admit the Deanship of Scientific Research at Najran University, Najran, Saudi Arabia for financial support to publish this research work in BJB successfully.

\section{References}

ABOYADAK, I.M., ALI, N.G.M., GODA, A.M.A.S., ABOELGALAGEL, W.H. and SALAM, A., 2015. Molecular detection of Aeromonas hydrophila as the main cause of outbreak in tilapia farms in Egypt. Journal of Aquaculture and Marine Biology, vol. 2, no. 6, pp. 2-5. http://dx.doi.org/10.15406/jamb.2015.02.00045.

ALGAMMAL, A.M., MOHAMED, M.F., TAWFIEK, B.A., HOZZEIN, W.N., EL KAZZAZ, W.M. and MABROK, M., 2020. Molecular typing, antibiogram and PCR-RFLP Based Detection of Aeromonas hydrophila complex isolated from Oreochromis niloticus. Pathogens, vol. 9, no. 3, pp. 238. http://dx.doi.org/10.3390/ pathogens9030238. PMid:32235800.

ALI, S., AKHTER, S., MUHAMMAD, A., KHAN, I., KHAN, W.A., IQBAL, M.N., UMAR, S., AHMED, H. and ALI, Q., 2016 [viewed 30 July 2021]. Identification, Characterization and Antibiotic Sensitivity of Aeromonas hydrophila, a Causative Agent of Epizootic Ulcerative Syndrome in Wild and Farmed Fish from Potohar. Pakistan Journal of Zoology [online], vol. 48, no. 3, pp. 899-901. Available from: https://www.researchgate.net/profile/ Shahzad-Ali-14/publication/304785197

CASCÓN, A., YUGUEROS, J., TEMPRANO, A., SÁNCHEZ, M., HERNANZ, C., LUENGO, J.M. and NAHARRO, G., 2000. A Major secreted elastase is essential for pathogenicity of Aeromonas hydrophila. 
Infection and Immunity, vol. 68, no. 6, pp. 3233-3241. http:// dx.doi.org/10.1128/IAI.68.6.3233-3241.2000. PMid:10816468.

DIAS, C., MOTA, V., MARTINEZ-MURCIA, A. and SAAVEDRA, M.J., 2012. Antimicrobial resistance pattern of Aeromonas spp. isolated from ornamental fish. Journal of Aquaculture Research E Development, vol. 3, no. 3, pp. 1-4. http://dx.doi. org/10.4172/2155-9546.1000131.

DONG, H.T., TECHATANAKITARNAN, C., JINDAKITTIKUL, P., THAIPRAYOON, A., TAENGPHU, S., CHAROENSAPSRI, W., KHUNRAE, P., RATTANAROJPONG, T. and SENAPIN, S., 2017. Aeromonas jandaei and Aeromonas veronii caused disease and mortality in Nile tilapia, Oreochromis niloticus. Journal of Fish Diseases, vol. 40, no. 10, pp. 1395-1403. http://dx.doi.org/10.1111/ jfd.12617. PMid:28383126.

EID, H., SOLIMAN, Z. and HANAFY, A.S., 2019. Molecular detection of some virulence genes in Aeromonas species isolated from fishes and water of Manzala Lake. Suez Canal Veterinary Medical Journal, vol. 24, no. 2, pp. 231-243. http://dx.doi.org/10.21608/ scvmj.2019.69847.

EL LATIF, A.M.A., ELABD, H., AMIN, A., ELDEEN, A.I.N. and SHAHEEN, A.A., 2019. High mortalities caused by Aeromonas veronii: identification, pathogenicity, and histopathological studies in Oreochromis niloticus. Aquaculture International, vol. 27, no. 6 , pp. 1725-1737. http://dx.doi.org/10.1007/s10499-019-00429-8.

ELSHESHTAWY, A., YEHIA, N., ELKEMARY, M. and SOLIMAN, H., 2019. Investigation of Nile tilapia Summer mortality in Kafr El-Sheikh Governorate, Egypt. Genetics of Aquatic Organisms, vol. 3, no. 1, pp. 17-25. http://dx.doi.org/10.4194/2459-1831-v3_1_03.

GONZÁLEZ-SERRANO, C.J., SANTOS, J.A., GARCÍA-LÓPEZ, M.L. and OTERO, A., 2002. Virulence markers in Aeromonas hydrophila and Aeromonas veroniibiovarsobria isolates from freshwater fish and from a diarrhoea case. Journal of Applied Microbiology, vol. 93, no. 3, pp. 414-419. http://dx.doi.org/10.1046/j.13652672.2002.01705.x. PMid:12174039.

GOVIND, P., SHRIVASTAV, A.B. and MADHURI, S., 2012 [viewed 30 July 2021]. Fishes of Madhya Pradesh with special reference to zebrafish as model organism in biomedical research. International Research Journal of Pharmacy [online], vol. 3, no. 1, pp. 120-123. Available from: https://agris.fao.org/agris-search/ search.do? recordID=AV2012079627

HASSAN, M.A., NOURELDIN, E.A., MAHMOUD, M.A. and FITA, N.A., 2017. Molecular identification and epizootiology of Aeromonas veronii infection among farmed Oreochromis niloticus in Eastern Province, KSA. Egyptian Journal of Aquatic Research, vol. 43, no. 2, pp. 161-167. http://dx.doi.org/10.1016/j.ejar.2017.06.001.

HOSSAIN, S., SILVA, B.C.J., DAHANAYAKE, P.S., DE ZOYSA, M. and HEO, G.J., 2020. Phylogenetic characteristics, virulence properties and antibiogram profile of motile Aeromonas spp. isolated from ornamental guppy (Poecilia reticulata). Archives of Microbiology, vol. 202, no. 3, pp. 501-509. http://dx.doi.org/10.1007/s00203019-01762-5. PMid:31707424.

JAGODA, S.D.S., WIJEWARDANA, T.G., ARULKANTHAN, A., IGARASHI, Y., TAN, E., KINOSHITA, S., WATABE, S. and ASAKAWA, S., 2014. Characterization and antimicrobial susceptibility of motile Aeromonads isolated from freshwater ornamental fish showing signs of septicaemia. Diseases of Aquatic Organisms, vol. 109, no. 2, pp. 127-137. http://dx.doi.org/10.3354/dao02733. PMid:24991740.

KISHK, D.M., MOUSTAFA, N.Y. and KIRRELLA, G.A.K., 2020. Prevalence and virulence characteristics of Aeromonas species isolated from fish farms in Egypt. Kafrelsheikh Veterinary Medical Journal, vol. 18, no. 2, pp. 5-8. http://dx.doi.org/10.21608/kvmj.2020.115274.
LAITH, A.R. and NAJIAH, M., 2014 [viewed 30 July 2021]. Aeromonas hydrophila: antimicrobial susceptibility and histopathology of isolates from diseased catfish. Journal of Aquaculture Research E' Development [online], vol. 5, no. 2, pp. 215. Available from: https://www.cabdirect.org/cabdirect/abstract/20143259523

LEE, C., CHO, J.C., LEE, S.H., LEE, D.G. and KIM, S.J., 2002. Distribution of Aeromonas spp. as identified by $16 \mathrm{~S}$ rDNA restriction fragment length polymorphism analysis in a trout farm. Journal of Applied Microbiology, vol. 93, no. 6, pp. 976-985. http://dx.doi. org/10.1046/j.1365-2672.2002.01775.x. PMid:12452953.

LI, J., NI, X.D., LIU, Y.J. and LU, C.P., 2011. Detection of Virulence gene alt, aph and aerA in Aeromonas hydrophila and their relationship with actual Virulence Zebrafish. Journal of Applied Microbiology, vol. 110, no. 3, pp. 823-830. http://dx.doi.org/10.1111/j.13652672.2011.04944.x. PMid:21219556.

MANSOUR, A., MAHFOUZ, N.B., HUSIEN, M.M. and ABU EL-MAGD, M., 2019. Molecular identification of Aeromonas hydrophila strains recovered from Kafrelsheikh fish farms. Slovenian Veterinary Research, vol. 56, no. 22, pp. 201-208. http://dx.doi. org/10.26873/SVR-758-2019.

MARKOV, G., KIROV, G., LYUTSKANOV, V. and KONDAREV, M., 2007. Necrotizing Fasciitis and Myonecrosis due to Aeromonas hydrophila. Wounds : a Compendium of Clinical Research and Practice, vol. 19, no. 8, pp. 223-226. PMid:26110366.

MATTER, A.F., EL ASELY, A.M., SHAHEEN, A.A., EL-GAWAD, E.A.A., EL-ABD, H. and ABBASS, A.A., 2018 [viewed 30 July 2021]. Phenotypic and molecular characterization of bacterial pathogens isolated from diseased freshwater fishes. International Journal of Fisheries and Aquatic Studies [online], vol. 6, no. 2, pp. 34-41. Available from: https://www.fisheriesjournal.com/ archives/2018/vol6issue2/PartA/6-1-75-378.pdf

MERT, R. and BULUT, S., 2014 [viewed 30 July 2021]. Some biological properties of carp (Cyprinus carpio L., 1758) introduced into Damsa Dam Lake, Cappad Cia Region, Turkey. Pakistan Journal of Zoology [online], vol. 46, no. 2, pp. 337-346. Available from: https://d1wqtxts1xzle7.cloudfront.net/46697081/

MZULA, A., WAMBURA, P.N., MDEGELA, R.H. and SHIRIMA, G.M., 2020. Virulence pattern of circulating aeromonads isolated from farmed Nile tilapia in Tanzania and novel antibiotic free attenuation of Aeromonas hydrophila strain TZR7-2018. Aquaculture Reports, vol. 17, pp. 100300. http://dx.doi. org/10.1016/j.aqrep.2020.100300.

NAHAR, S., RAHMAN, M.M., AHMED, G.U. and FARUK, M.A.R., 2016 [viewed 30 July 2021]. Isolation, identification, and characterization of Aeromonas hydrophila from juvenile farmed pangasius (Pangasianodon hypophthalmus). International Journal of Fisheries and Aquatic Studies [online], vol. 4, no. 4, pp. 52-60. Available from: https://d1wqtxts1xzle7.cloudfront. net $/ 57138275 / 2016$

NHINH, D.T., LE, D.V., VAN, K.V., HUONG-GIANG, N.T., DANG, L.T. and HOAI, T.D., 2021. Prevalence, virulence gene distribution and alarming the multidrug resistance of Aeromonas hydrophila associated with disease outbreaks in freshwater aquaculture. Antibiotics, vol. 10, no. 5, pp. 532. http://dx.doi.org/10.3390/ antibiotics10050532. PMid:34064504.

OIDTMANN, B., STEINBAUER, P., GEIGER, S. and HOFFMANN, R.W., 2008. Experimental infection and detection of Aphanomyces invadans in European catfish, rainbow trout and European eel. Diseases of Aquatic Organisms, vol. 82, no. 3, pp. 195-207. http:// dx.doi.org/10.3354/dao01973. PMid:19244971.

PEEPIM, T., DONG, H.T., SENAPIN, S., KHUNRAE, P. and RATTANAROJPONG, T., 2016. Epr3 is a conserved immunogenic protein among Aeromonas species and able to induce antibody 
response in Nile tilapia. Aquaculture, vol. 464, pp. 399-409. http://dx.doi.org/10.1016/j.aquaculture.2016.07.022.

PRIDGEON, J.W. and KLESIUS, P.H., 2011. Molecular identification and virulence of three Aeromonas hydrophila isolates cultured from infected channel catfish during a disease outbreak in west Alabama (USA) in 2009. Diseases of Aquatic Organisms, vol. 94, no. 3, pp. 249-253. http://dx.doi.org/10.3354/dao02332. PMid:21790073.

RAB, A., AFZAL, M., AKHTAR, N., BARLAS, A. and QAYYUM, M., 2001 [viewed 30 July 2021]. Incidence of epizootic ulcerative syndrome (EUS) in freshwater fishes in the endemic area of Punjab, Pakistan. Bangladesh Journal of Fisheries Research [online] vol. 5, no. 1, pp. 45-52. Available from: http://aquaticcommons. org/17660/

ROGES, E.M., GONÇALVES, V.D., CARDOSO, M.D., FESTIVO, M.L., SICILIANO, S., BERTO, L.H., PEREIRA, V.L.A., RODRIGUES, D.P. and AQUINO, M.H.C., 2020. Virulence-associated genes and antimicrobial resistance of Aeromonas hydrophila isolates from animal, food, and human sources in Brazil. BioMed Research International, vol. 2020, pp. 1052607. http://dx.doi. org/10.1155/2020/1052607. PMid:32461959.

SARKAR, A., SAHA, M. and ROY, P., 2013. Detection of 232bp virulent Gene of pathogenic Aeromonas hydrophila trough PCR based techniques: a rapid molecular diagnostic approach. Advances in Microbiology, vol. 3, no. 1, pp. 83-87. http://dx.doi.org/10.4236/ aim.2013.31013.

SHAHZAD, A., IAHTASHAM, K., QURBAN, A., ULLAH, K.S., SHARIF, M.Z. and SHAMIM, A., 2014 [viewed 30 July 2021]. Isolation and identification of Aeromonas sorbia in Catla catla (Thaila) affected with hemorhegic septicaemia. Bulletin of the European Association of Fish Pathologists [online], vol. 34, no. 2, pp. 35. Available from: https://www.researchgate.net/profile/ZahidMirza/publication/263851162

SHAO, J.Z., LIU, J. and XIANG, L.X., 2004. Aeromonas hydrophila induced apoptosis in Carassius auratus lymphocytes in vitro. Aquaculture, vol. 229, no. 1-4, pp. 11-23. http://dx.doi. org/10.1016/S0044-8486(03)00364-8.
SINGH, V., SOMVANSHI, P., RATHORE, G., KAPOOR, D. and MISHRA, B.N., 2009. Gene cloning, expression and homology modeling of hemolysin gene from Aeromonas hydrophila. Protein Expression and Purification, vol. 65, no. 1, pp. 1-7. http://dx.doi.org/10.1016/j. pep.2008.11.015. PMid:19136063.

TRAKHNA, F., HARF-MONTEIL, C., ABDELNOUR, A., MAAROUFI, A. and GADONNA WIDEHEM, P., 2009. Rapid Aeromonas hydrophila identification by TaqMan PCR assay: comparison with a phenotypic method. Letters in Applied Microbiology, vol. 49, no. 2, pp. 186-190. http://dx.doi.org/10.1111/j.1472765X.2009.02635.x. PMid:19413760.

VIJI, V.T., BABU, M.M., VELMURUGAN, S., KUMARAN, T., ANAND, S.B., GUNASEKARAN, P. and CITARASU, T., 2012. Virulence factors and molecular cloning of outer membrane protein (OMP) gene from virulent Aeromonas hydrophila isolated from infected gold fish Carassius auratus. Bangladesh Journal of Microbiology, vol. 28, no. 2, pp. 70-75. http://dx.doi.org/10.3329/bjm.v28i2.11819.

WANG, G., CLARK, C.G., LIU, C., PUCKNELL, C., MUNRO, C.K., KRUK, T.M., CALDEIRA, R., WOODWARD, D.L. and RODGERS, F.G., 2003. Detection and characterization of the hemolysin genes in Aeromonas hydrophila and Aeromonas sobriaby multiplex PCR. Journal of Clinical Microbiology, vol. 41, no. 3, pp. 10481054. http://dx.doi.org/10.1128/JCM.41.3.1048-1054.2003. PMid:12624028.

WANJA, D.W., MBUTHIA, P.G., WARUIRU, R.M., MWADIME, J.M., BEBORA, L.C., NYAGA, P.N. and NGOWI, H.A., 2019 [viewed 30 July 2021]. Bacterial pathogens isolated from farmed fish and source pond water in Kirinyaga County, Kenya. International Journal of Fisheries and Aquatic Studies [online], vol. 7, no. 2, pp. 34-39. Available from: https://d1wqtxts1xzle7.cloudfront. net/59108716

ZHOU, Q.L., WANG, Y.J., XIE, J., GE, X.P., XI, B.W. and LIU, B., 2013. Distribution and virulence gene comparison of Aeromonas strains isolated from diseased fish and water environment. Polish Journal of Microbiology, vol. 62, no. 3, pp. 299-302. http:// dx.doi.org/10.33073/pjm-2013-039. PMid:24459836. 